\title{
The Muslim Women Figure in the Sibel Eraslan's Khadijah: Ketika Rahasia Mim Tersingkap
}

\author{
Inden Swastika* \\ Indonesian Language and Literature Education of \\ Graduate School \\ Universitas Negeri Yogyakarta \\ Yogyakarta, Indonesia \\ indenswastika20@gmail.com
}

\author{
Wiyatmi \\ Indonesian Language and Literature Education of \\ Graduate School \\ Universitas Negeri Yogyakarta \\ Yogyakarta, Indonesia \\ wiyatmi@uny.ac.id
}

\begin{abstract}
Moslem women's live is not proportionally pictured in mainstream media. They are said to have a very limited access to so many things and can't do their activities freely. Literary works can contribute in providing different angles to open up society's point of view. This study, aims at describing the exixtence of Moslem women in carrying out their obligations in accordance to the teachings of Islam depicted in Sibel Eraslan's Khadijah: Ketika Rahasia Mim Tersingkap. This descriptive qualitative research used reading and note taking in data collection. The data analysis consisted of data reductions, data display, and conclusions drawing or verification. The data were statements, speeches, narration, and behaviors of the characters taken from the novel and interpreted using the Islamic Feminism perspective- the study of feminism based on Qur'an and Hadith. The Findings consist of first, Khadijah, Dujayah, Berenis, Zainab and Fatimah are the five Moslem women figures found in the novel, second, each character had their own role as a Moslem woman: as a child, a wife, a mother, and a family carer. Third, every Moslem women in the novel has properly conducted their obligations and are not at all chained like what the society always believes on.
\end{abstract}

Keywords-Moslem women, Khadijah, Islamic feminism

\section{INTRODUCTION}

Today's readers have various options of literary works that they can read. They can easily read works by both local and international authors. Works from the western countries are highly demanded although currently works from Middle Eastern writers have gained more attention from Indonesian. especially when the stories are evolving around the topic of Islamic religion, values, and teachings. The Middle east literary works are continually translated into Bahasa Indonesia and repeatedly printed to meet the Moslem readers' demand in Indonesia. It is very easy to find such books in book stores nowadays.

Stories are one of the Arabic cultures but only very few people are capable of retelling the stories by using the Arabic language well. The local literatures are continuously wiped away by the language barrier, permanently the creativity is kept in silent too, and these stories have not been written widely yet. It is surprising if the non-Moslem society perceived that Islam is the underdog and the oppressed religion (Leila, 200: 78-97) although in reality Islam is the religion that appreciates and glorifies women and it is beautifully depicted in Khadijah: Ketika Rahasia
Mim Tersingkap. This particular work is hoped to deflect those stereotyping statements as mentioned above.

Literary works are imaginary works or fiction. Even though that literary work was taken or influenced by a real story, the writer has processed the stories and combined it with their own imagination so it cannot be called the same as the real story anymore (Noor, 2006: 11). One of the requirements for a piece of writing to be called a literary work is that it has to be written and printed (Wellek and Warren, 1995: 11). There are several types of literary works and one of it is a novel and in this research a novel entitled Khadijah: Ketika Rahasia Mim Tersingkap by Sibel Eraslan is the object of the analysis.

The novel Khadijah: Ketika Rahasia Mim Tersingkap is a novel that translated from Turkish's novel entitled Col ve Deniz published in Istanbul in 2009 and firstly published in Indonesia in 2013. in 2018 the novel is already in its $13^{\text {th }}$ reprinting. The novel tells readers about the main character in the story named Khadijah. The story begins before she was born until the death of the main character. In the story, Khadijah is the daughter of a man named Khuwaylid bin Asad and her mother's name is Fatimah binti Zidah. The story does not only tell readers about the life of Khadijah but also some other Moslem women figures like Dujayah, Berenis, Zainab and Fatimah who have their own roles in the story also. As has been explained formerly that the purpose of the study is to open up the new perspectives towards Moslem women through literary works. An Islamic feminism framework is used in the analysis to show readers a different dimension of portraying women in Islam. The Islamic feminism has multiple interpretations, but the main purpose is the processing of realizing and changing as the desire of solving the inequality and the injustice (Hidayatullah, 2010: 7). Women in Islam are pictured to have gotten the domestic roles even though in several necessities and requirements they have gotten the permission to take a role in public (Ilyas, 2015: 223). The novel Khadijah: Ketika Rahasia Mim Tersingkap shows he Islamic women's life or the Moslem women in the Arabic culture as their background.

Dastgeer and Gade (2016: 1-19) explain that public discourse, the private problem about women are interesting points to talk about. It has been observed differently from several point of views including the Moslem women in Arabic world, the Islamic feminism, the views of sociology, 
and their visual framing of the women too. In addition, MacLarney (2010: 129-148) explains that public discourse, personal issues about women are interesting to talk about. The presentation by Treacher and Shukrallah (2005: 4-14) about feminist and Arabic women has created pros and cons, women who do outdoor activities need to make sure that their families are not suffering. However, those outdoor activities have risen worries in Arabic society as they require women to be wives and mothers and these roles should not be neglected.

Some distinctions and views about Moslem women by some people, make this research important to be done. Some negative views keep continuing to emerge because of their ignorance about the lives of Moslem women. Moslem women are totally misjudged because their activities are limited. Through the media like literature, this research aimed to open up the society point of view about the life of Moslem women according to the teachings of Islam.

The life of Moslem women is regulated already in the Qur'an and Hadith. A woman's obligations must be fulfilled so that the Islamic Shari'a will continue to be implemented properly. Obligations of Moslem women are the destination and Islam highly glorifies women. There were some obligations that have to be accepted by Moslem women as follows.

\section{A. The Obligations of Moslem Women to Their Parents.}

A Moslem woman must meet the needs of their parents like serving both of them, obeying them while they are worshiping Allah, and helping them as best as she can as long as their life. After the two died, she has to maintain the connection of the parents' relationship with their parents' friends, make charity for their names, and pray for both of them too. Those are the right of the parents (Al-Ghamidi, 2019: 155-157) which are already explained in the Qur'an in Surah Al-Isra: 23.

\section{B. The obligations of Moslem Women to Her Husband}

A wife gets a title as being Salihah because she has placed obedience to her husband as a priority and makes it a form of devotion to her husband. She should fulfill all the wishes of the husband as has been prescribed, his right to enjoy marriage life as a whole and perfect, and has the intimate time well because this is the main purpose of marriage. According to the Quran in the Surah Ar-Rum: 21 21 , the character which is expected from wives is qana'ah, sam' $u$, and tha'ah (accepting what we are, willing to listen, and obeying), (Al-Ghamidi, 2019: 157-160).

\section{The Obligations of Moslem Women to Their Children}

The Successful mothers would work with their husbands to educate their children together. They need to help each other to find solutions towards problems. A child always stays with his mother in the times of growth and preschooling period. A mother who instills the noble meanings about her Rabb (God) in her children, her Prophet, her religion, her parents, society, and people and if a mother succeeds in instilling those, then she has implemented a madrasa (school); and this madrasa has a very big influence on the child throughout his life (Al-Ghamidi: 2019:160-
162). The Quranic verse that explains this is the surah AtTahrim: 6.

Based on Islamic teachings, every "mandate of God" should be protected and maintained, following the wishes of God, as an obligation which is full of responsibility to both of the parents (Majelis Tarjih dan Tajdid Pimpinan Pusat Muhammadiyah, 2017: 16-17). Engineer (1992: 42) mentions that the activities and tasks of caring and educating the children are a shared responsibility. The Qur'an is very friendly to the women and to the weak people.

\section{The Obligations of Moslem Women to the Families, Relatives, and Neighbors}

A Moslem woman should stay in touch and strengthen the connection with her relatives. It is an obligation to visit the neighbors, best friends, and relatives in due times, to help each other in kindness, and to treat their neighbors kindly. She must be honest, happy to give advice, and must have a sense of pudency and good manners too. A Moslem woman should be just, clear with what she likes and dislikes, non-judgemental, and careful as not to violate other people's rights. In addition, the nature that cannot be left out of the figure of Moslem women in society is a generous and charitable characterization (Al-Ghamidi, 2019: 162-167). This part is explained in the Quran Surah An-Nisa: 1.

\section{RESEARCH METHODS}

This study belongs to a descriptive qualitative research which aims at discovering the symptoms based on the problem formulations list. The data were statements, speeches, narration, and behaviors of the characters taken from the novel Sibel Eraslan's Khadijah: Ketika Rahasia Mim Tersingkap. This research used reading and note taking in data collection and the human instrument as the instrument of the data collection. The data analysis consisted of data reductions, data display, and conclusions drawing or verification, (Miles and Huberman, 2014:10-12). The data were then interpreted using the Islamic Feminism (the study of feminism based on Qur'an and Hadith perspective) as the base of the theory. In this study, the steps were done as follows. (1) Reduction data for selecting the important things in the novel that were related to the Moslem women. (2) Display data to categorize the data of women's obligation based on the obtained data and the outlined data. (3) Conclusions drawing/verification to make an incompatibility and the verifications.

\section{FINDINGS AND DISCUSSION}

Based on the research analysis, the findings of the study are as follows:

\section{A. The Obligation of Moslem Woman to Their Parents}

The data shows that there is a Moslem woman, Khadijah who had done her obligation towards her parents.

"Duhai buah hati anak wanitaku yang terlahir lebih awal. Bangunlah di awal waktu dan segeralah bergegas menempuh perjalanan.”

"Baiklah Ayahanda." 
Dengan membawa nama yang telah bersemayam di hati padang sahara, Khadijah akan memulai awal langkah perjalanan untuk menjari ratu padang pasir. Begitulah apa yang ditakdirkan dengan namanya (Eraslan, 2018:4).

According to the quotations above, Khadijah was an obedient daughter. Khadijah's father once asked her to leave Mecca because the situation was too danger at that time. As a Moslem woman it is a must to fulfill their parents' request as long the requests do not violate the Islamic sharia. Even she had to cross the desert, she would say 'yes' and would not neglect it. Afterwards, there is Zainab that has been described as a character that loves her father.

Zainab segera menyerahkan kendi berisi air yang ada di sampingnya kepada sang ayah. Dengan bibir berdarah-darah, seraya mengucap basmalah, sang ayah mulai meneguk air dari kendi itu. Setelah mencuci wajahnya, tampak sebagian dari air itu bercampur darah dan peluh. Ketika membersihkan pakaiannya yang berdebu, tersenyumlah ia kepada putrinya. Dan ketika Zainab tidak bisa menahan dirinya untuk menangis, seperti biasa, sang ayah akan mengelus kepala putrinya sembari berkata, "Zainab... oh Zainab." (Eraslan, 2018: 329).

The quotation above describes that Zainab met her father by covering her face to avoid recognition by strangers. She could not handle the feeling when she saw her father was mocked and tortured while he was preaching at the market. A daughter's love had been shown when she brought water for her father who was in pain. The action depicted that Zainab loved her father so much. The next Moslem woman figure is Fatimah; she was Zainab's little sister. who had similar character to Zainab, she was an obedient daughter too.

Fatimah mendekap erat kaki Ibunya, menangis tanpa suara. Diusaplah rambut putrinya itu. Ia lalu meminta air. Adakah waktu tersisa untuk air? Namun, ia meminta kepada Fatimah. Jelaslah, bahwa setelah ini Fatimahlah yang akan membawakan air. Seperti wasiat yang turun-temurun diberikan dari Hajar ke Khadijah, dan kini dari Khadijah ke Fatimah (Eraslan, 2018: 377).

The quotations show the little Fatimah fully understood the pain of her mother. She tried not to be a burden for her mother. She did not whine and she served her mother sincerely. That is how a Moslem woman is expected to behave to the parents.

\section{B. The Obligations of Moslem Women to Their Husband}

The data from quotation below shows that there was a figure of Moslem woman (Moslema) who served her husband as part of her obligations towards her husbands.

Bahkan, mereka sering mengirim utusan kepada Khadijah untuk mengadukan perihal itu. Khadijah mendengarkan orang-orang yang datang mengeluh tanpa menyinggung perasaan. Dengan sopan, dia mencoba menjelaskan bahwa akhlak suaminya merupakan kehormatan bagi keluarga dan umat manusia (Eraslan, 2018: 212).

Khadijah pada dasarnya merupakan wanita yang selalu taat kepada hukum. Sebab itulah dia dihormati oleh semua orang. Namun, setelah melihat dan menjadi saksi atas penerapan akhlak yang bagus oleh suaminya, dia memutuskan menjadikan contoh-contoh perbuatan bagus itu sebagai tujuan hidupnya. Dia sekali lagi percaya kepadanya, sekali lagi jatuh cinta kepadanya setiap hari (Eraslan, 2018: 226).

The two quotations above show that Khadijah was a wife who always protected her husband's image, she honored it. She kept calm when everybody was busy talking about her husband, and even she explained the truth with calmly. Khadijah also followed her husband's good attitude and it was shown that Khadijah was an obedient wife too. Other that that the figure of Khadijah was the typical wife who could pacify her husband.

Tangan-tangan kasih sayang Khadijah dengan cepat menyelimuti tubuh al-Amin ketika ia berkata, "Selimuti aku!" Dan ucapan-ucapan Khadijah yang menenagkan al-Amin merupakan ilham dan ampunan yang diberikan oleh Allah (Eraslan, 2018: 271).

The quotation above shows that Khadijah was a patient wife when she was caring her husband. When her husband asked her to cover his body after getting his first revelation, she followed his order and it calmed her husband's heart immediately.

\section{The obligations of Moslem Women to Their Children}

Moslemas are also depicted as having an obligation towards their children as well.

Perjuangan itu tentu saja penuh kepedihan dan kekhawatiran. Bagaimana tidak, bagi seorang wanaita, perjalanan tengah malam di Mekah tentu sangat membahayakan keselamatan. Peristiwa ini akan memberikan pelajaran tentang betapa susah dan berbahaya berjalan di tengah-tengah malam bagi seorang Ibu yang hanya ditemani pelayan wanitanya sambil mendekap erat-erat anaknya yang sedang sekarat (Eraslan, 2018: 22).

The quotations pointed Khadijah's struggle as a mother who fought her fears by walking through the night getting a doctor to heal her sick daughter, Hindun. She took the journey all on her own without her husband's company, Abu Hala bin Zurara, because he already passed away. She did everything to save her daughter. The love of mother to her children can also be seen in the following quotations:

Dan kemudian, dua anak perempuan, Rukayah dan Ummu Kultsum, lahir ke dunia setelah Zainab. Zainab, Zaid, Zubair, Ali, Ruqayyah, dan Ummu Kulstum uang tumbuh besar di bawah tangan Khadijah akan menorehkan sejarah di lembaran-lembaran halaman emas sebagai anak-anak yang berharga (Eraslan, 2018: 243). 
Permasalahan anak perempuan mereka, Hindun binti Atik, yang saat itu sudah berada di usia untuk menikah merupakan salah satu contoh. Khadijah ikut memikirkan persiapan pernikahan, dengan siapa akan menikah, dan juga permasalahan-permasalahan rumah tangga yang akan dibangun. Sayfi bin Umayyah, keponakannya, pernah meminang Hindun, tetapi Khadijah tidak terburu-buru memberikan keputusan. Ia memberitahu dan mendiskusikan masalah-masalah seperti itu kepada al-Amin pada saat suaminya tidak sibuk dan dalam kondisi yang nyaman (Eraslan, 2018: 258).

The quotations above show that Khadijah was a loving mother. She taught her children well without discriminating one from the other, the justice was in her character. Khadijah consulted every decision about her children with her husband. Khadijah always tried to meet her children's necessities even when she was in a difficult situation as described in the following quotations.

"Bismillah." Dadanya diperas seraya menyebut asma Allah.

Tidak keluar air susu...

Bismillah...

Masih tidak keluar...

"Ya Rabb, berilah pertolongan untuk rumah utusan-Mu. Bismillah..." rintihnya.

Kali ketiga, karena begitu keras memeras, yang keluar adalah susu bercampur darah (Eraslan, 2018: 326).

The quotations above describe when Khadijah was trying hard to breastfeed Abdullah, her son. Her soul was trembling by hearing that her husband suffered from gotten a bad treatment from the society because he preached the truth. That accident impacted Khadijah's condition that her breasts could not give her children the milk that they needed.

D. The Obligations Of Moslem Women to The Families, Relatives, and Neighbors

Moslem women have obligations towards their neighbors and relatives.

Berenis mendapat tugas menjahit karena dia lebih berpengalaman dibandingkan yang lain. Sementara itu, Dujayah menjadi pendamping Berenis dan bertugas memotong tali-tali menjadi tipis. Selain itu, ia juga bertugas mengikat kain-kain wol putih yang berbentuk bulat yang dikerjakan para nenek. Membentuk kain wol menjadi bulatan lebih kecil memamang menjadi tugas para wanita muda. Di "hari kain wol" ini, para wanita bermacam umum diselimuti rasa khawatir yang manis (Eraslan, 2018: 280).

It is described here when Khadijah's servants, Berenis and Dujayah were preparing for Zainab's wedding. These servants performed their duties joyously. They welcomed the event and helped each other so the big day could run well. The act of both of them showed that the Moslem women could freely do outside the house-activities.
Khadijah is depicted as a passionate person towards the elderlies in her neighborhood too.

Bersama dengan Khadijah, al-Amin sering pergi mengunjungi orang-orang tua yang sedang melakukan pengasingan diri di gunung dan sibuk dengan puasa dan berdoa. Pada saat seperti itu, Khadijah akan menaruh makanan, seperti zaitun dan kurma, di kerangjang yang ia bawa dan diberikan kepada mereka yang berhari-hari beridam diri di dalam gua. Setelah itu, Khadijah akan meminta didoakan oleh mereka (Eraslan, 2018: 245).

The quotations above describe Khadijah's participation in visiting people. The visiting was one of the efforts of connecting kinship. In addition, she also had a generous character because she shared foods with people she met. Khadijah's generosity is pictured below in the part that describes how she devoted all her energy and wealth to people who were in need.

Sebisa mungkin Khadijah merawat, mengawasi, dan memeriksa pasien-pasiennya. Suara-suara rintihan dari kamar-kamar dan taman itu membuatnya tak pernah merasakan kantuk hingga pagi menjelang (Eraslan, 2018: 355)

Dialah Khadijah, pemilik penginapan yang dulunya kerap dijadikan tempat singgah kereta-kereta yang membawa beludru dan sutra yang sangat berharga di dunia pada masanya. Dialah Khadijah, pemilik unta yang jumlahnya sedemikian banyak hingga Lembah Ajyad tak kuasa lagi menampung mereka. Dan semua harta yang luar biasa banyaknya itu habis diinfakkan untuk kaum mukminin selama harihari pemboikotan berlangsung (Eraslan, 2018: 374).

The two quotations above show the figure of Khadijah. She was a kind person that would do everything to help people who were suffering in pain because they had believed in the truth that was brought by the prophet Muhammad. Nursing the sick people was one of the good values that Khadijah showed as a Moslema and it was not only that, Khadijah was also a generous person, she donated all her wealth in the name of Allah. She was known as a wealthy merchant which also proofed that a moslema could do activities outside her home without neglecting her obligation as a child, a wife, a mother, and a society member.

\section{CONCLUSION}

The findings of this study were based on the analysis and discussion that had been conducted on the novel Khadijah: Ketika Rahasia Mim Tersingkap by Sibel Eraslan. The subject was the form of Moslem women's obligations which can be described as follows. First, there were five Moslem female figures in the novel named Khadijah as the main figure and Dujayah, Berenis, Zainab, and Fatimah as the accompanying figures. Second, Khadijah was a person who served the obligations of a Moslem woman to her parents, husband, children and relatives. Dujayah and Berenis were Moslem women who had done their obligations towards relatives, they were both a servant too. In addition, there are figures of Zainab and Fatimah who were Moslem women who obeyed their obligations as 
children. Third, every Moslem woman in this novel had met their obligations based on the Islamic teachings were not chained like what the society always believes on.

\section{ACKNOWLEDGMENT}

The writers wish to thank Allah the most merciful for allowing this project to finish smoothly and that Dr. Kastam Syamsi, M.Ed at the Indonesian Language and Literature Education study program, Postgraduate Program, Yogyakarta State University.

\section{REFERENCES}

Al-Ghamidi, Ali bin Sa'id. (2019). Fikih Wanita. Solo: Aqwan Media Profetika.

Dastgeer, Shugofa dan Peter J Gade. (2016). Visual framing of Moslem Women in the Arab Spring: Prominent, active, and visible. UK: University of Oklahoma. Vol.78, No.5. 1-19.
Engineer, Asghar Ali. (1992). The Right of Women In Islam. Malaysia: IBS Buku SDN BHD.

Eraslan, Sibel. (2018). Khadijah: Ketika Rahasia Mim Tersingkap (terjemahan). Jakarta: Kaysa Media.

Hidayatullah, Syarif. (2010). Teologi Feminisme Islam. Yogyakarta: Pustaka Pelajar.

Ilyas, Yunahar. (2015). Kesetaraan Gender dalam Al-Qur'an Studi Pemikiran Para Musafir. Yogyakarta: ITQAN Publishing.

Leila, Ahmed. (2000). The Women of Islam. Indiana University Press. Vol. 9, No. 3. 78-97.

Majelis Tarjih dan Tajdid Pimpinan Pusat Muhammadiyah. (2017). Abadul Mar'ah Fil Islam. Yogyakarta: Suara Muhammadiyah.

McLarney, Ellen. (2010).The private is political: Women and Family in intellectual Islam. USA: Duke University. Vol. 11, No. 2. 129-148.

Miles, Matthew B dan A. Michael Huberman. (2014). Qualitative Data Analysis (terjemahan). Jakarta: UI Press.

Noor, Redyanto. (2006). Pengantar Pengkajian Sastra. Semarang: Fasindo. Treacher, Amal dan Shukrallah, Hala. (2005). The Realm of the Possible: Middle Eastern Women in Political and Social Spaces. Vol. 80, No. 1. 4-14.

Wellek, Rene dan Austin Warren. (1995). Teori Kesusastraan (terjemahan Melani Budianta). Jakarta: Gramedia Pustaka Utama. 